Explaining the entrepreneurial orientation-performance relationship in emerging economies: The intermediate roles of absorptive capacity and improvisation

Paul Hughes (corresponding author)

Professor of Strategic Management

Leicester Castle Business School

De Montfort University

Castle View

Leicester LE1 5WH

United Kingdom

Tel: +44 (0) 1162577031

Email: paul.hughes@dmu.ac.uk

Ian R. Hodgkinson

Senior Lecturer in Strategy

School of Business and Economics

Loughborough University

Loughborough LE11 3TU

United Kingdom

Tel: +44 (0) 1509223865

Email: I.R.Hodgkinson@lboro.ac.uk

Mathew Hughes

Professor of Entrepreneurship and Innovation

School of Business and Economics

Loughborough University

Loughborough LE11 3TU

United Kingdom

Tel: +44 (0) 1509223263

Email: M.Hughes2@lboro.ac.uk

Darwina Arshad

Senior Lecturer in Strategic Management

School of Business Management

Universiti Utara Malaysia

06010 UUM Sintok

Kedah Darul Aman

Malaysia

Tel: +604 9287439

Email: darwina@uum.edu.my 


\title{
Explaining the entrepreneurial orientation-performance relationship in Emerging Economies: The intermediate roles of absorptive capacity and improvisation
}

\begin{abstract}
Research has established the relevance of entrepreneurial orientation (EO) to firm performance but skepticism remains because of the ambiguity surrounding how EO might improve firm performance. We examine the key concepts of absorptive capacity and improvisation as two alternative learning modes serving as intermediate steps between EO and firm performance. Locating our study within manufacturing SMEs in Malaysia, we find that absorptive capacity enhances the EO-performance relationship, both as a moderator and a mediator. In contrast to expectations, however, improvisation showed no such effects but conferred its own separate benefits instead. We further discuss the different effects of these learning modes on high performance and low performance groups.
\end{abstract}

Keywords: Entrepreneurial orientation; Performance; Absorptive capacity; Improvisation; Emerging economies. 
How do firms from emerging economies generate performance returns from their entrepreneurial orientation? Entrepreneurial orientation (EO) is an important concept in entrepreneurship that captures an organizational decision-making posture regarding key firm-level activities, strategymaking practices, and managerial philosophies in the pursuit of new opportunities for firm growth and renewal (Wales, Parida, \& Patel, 2013a). EO is typically characterized by three dimensions: innovativeness, proactiveness, and a tendency to tolerate and accept risky behavior (Covin \& Slevin, 1989; Miller, 1983). The level of a firm's EO depends on the degree of these three dimensions, demonstrated in its actions or behaviors (Covin \& Lumpkin, 2011). While scholars have largely established the relevance of EO to firm performance, many questions remain about how EO affects performance and owing to what mechanisms (Engelen, Kube, Schmidt, \& Flatten, 2014; Wales, 2016). Failure of researchers to more fully address these questions has led to lingering skepticism about the practical value of EO (Wales, Monsen, \& McKelvie, 2011).

What is missing in theoretical and empirical treatments of EO to date is scrutiny of the intermediate steps between EO and firm performance (Real, Roldán, \& Leal, 2014; Wales, 2016). For example, Hmieleski and Corbett (2006) argue that scholars should examine the process through which EO delivers returns to firm performance, rather than its direct effect(s) alone. Specifically, Covin and Lumpkin (2011) argue that EO-performance relationships may be explained by learning-related processes and contextual factors, and the organizational learning activity of the firm can represent a vital intermediate step in the EO-performance relationship (Covin \& Lumpkin, 2011; De Clercq, Dimov, \& Thongpapanl, 2010).

The relative simplicity of the EO-learning-performance configuration examined to date in the literature is problematic, and belies a far greater complexity in how the EO-performance 
relationship may be influenced by modes of organizational learning. This problem has two parts. First, the dichotomy between deliberate and emergent processes of learning is a facsimile of the learning advantages-learning constraints challenge facing young firms as they grow and age (Hughes, Morgan, Ireland, \& Hughes, 2014). On the one hand, absorptive capacity, defined as organizing and assimilating newly-acquired knowledge, is a deliberate process of learning. On the other hand, organizational improvisation, defined as the abandonment of a deliberate process to gather and deploy information quickly, is not deliberate, but is an emergent process of learning. The effects of alternative learning modes represent an untreated dimension of the EOperformance relationship in the context of small-to-medium firms (Anderson, Covin, \& Slevin, 2009; Engelen et al., 2014; Wales et al., 2013b). It cannot be assumed that each mode will influence the EO-performance relationship equally. Left unaddressed, researchers may fail to fully resolve the key long-standing question of why some entrepreneurial firms continue to underperform against other entrepreneurial peers (Shane, 2010; Wang, 2008; Wang, Ahlstrom, Nair, \& Hang, 2008), even after a successful initial start-up (Gerber, 2004).

Second, studies have also shown that a direct test of the EO-performance relationship incompletely accounts for how EO can create sustainable superior performance (Real et al., 2014). This suggests that moderating and mediating effects exist. Allied to this, Bergh and Lim (2008) call for research to examine the distinctions between absorptive capacity and organizational improvisation for firm performance. The lack of research in this area limits researchers' ability to develop theory capable of predicting and explaining why one firm can maintain a positive EO-performance relationship in comparison to another. Drawing from two viewpoints of organizational learning that portray deliberate versus emergent action (Mintzberg \& Waters, 1985), that is, absorptive capacity and organizational improvisation (Bergh \& Lim, 
2008), we examine how learning modes affect the EO-performance relationship. More specifically, we examine the ability of (a) absorptive capacity and (b) improvisation to moderate and mediate the EO-performance relationship (Figure 1).

--Figure 1 about here-

We test our hypotheses using survey data from 111 Malaysian manufacturing small-tomedium sized enterprises (SMEs). Manufacturing SMEs represent one of the largest sectors in Malaysia driving recent and current economic growth there (Xavier \& Ahmad, 2012). Nevertheless, this emerging middle-income economy remains associated with low levels of organizational innovativeness and plateauing economic performance (Rigg, Promphaking, \& Le Mare, 2014). Multiple regression is used to test for the moderating and mediating effects of absorptive capacity and improvisation as two learning modes on the relationship between EO and firm performance. We analyze conditional effects for further understanding of the moderation results so as to uncover further differences in learning modes between groups of high and low performing SMEs. The study reveals that absorptive capacity enhances the EOperformance relationship as a mediator (and at upper-end values as a conditional effect), yet, in contrast to theoretical expectations, improvisation is unrelated to the EO-performance relationship but confers its own separate benefits instead.

This study makes two primary contributions. First, we offer a theoretical contribution by providing a learning-based view of EO that directs greater attention to the intermediate steps between EO and firm performance (Real et al., 2014; Wales et al., 2013b). To the best of our knowledge, this is the first study to demonstrate how the value of EO relies on the effect of absorptive capacity. This is despite longstanding concerns about the vulnerability of the EOperformance relationship to this learning mode (Yu, Hao, Ahlstrom, Si, \& Liang, 2014). Wales 
(2016) and Covin and Lumpkin (2011) expressed concern that relationships between EO and firm outcomes might be explained by learning-related processes and their contextual elements. Studies of EO and learning (e.g., Hughes, Hughes, \& Morgan, 2007; Keh, Nguyen, \& Ng, 2007; Li, Huang, \& Tsai, 2009; Wang 2008) have failed to distinguish between alternative learning modes that have very different learning-related processes and contextual elements at their heart. This oversight means that our current understanding of organizational learning in the EOperformance relationship, and capacity to predict the EO-performance relationship with theory, is at best incomplete and at worst misunderstood.

Second, we offer an empirical contribution by extending the geographic treatment of EO. EO research has concentrated primarily on more developed, Western economies (Kiss, Danis, \& Cavusgil, 2012), while the EO-performance relationship in emerging and middle-income economies has been neglected. Since theories, predictions, and causal mechanisms about EO originate outside these economies, there is a risk of flawed predictions about the merits and functions of EO for firms in emerging and middle-income economies being made. Building on notable investigations about entrepreneurship in emerging economies (e.g., Bruton, Ahlstrom, \& Oblój, 2008; Bruton, Ahlstrom, \& Si, 2015; Peng, 2001; Yu et al., 2014), we show the impact of alternative learning modes on the EO-performance relationship in an emerging middle-income economy.

\section{Theory}

EO and learning modes

EO has its heritage in upper echelon logic (Covin \& Miller, 2014) such that the practices and processes senior managers use to form and execute an entrepreneurial strategic posture for their 
firm relies on the actions and commensurate tactics they deploy across it (Covin \& Slevin, 1989; Lumpkin \& Dess, 1996). Why some SMEs underperform despite showing a clear EO is often a function of flaws in the learning architecture of the firm (Hughes et al., 2007, 2014) or knowledge deficits (Short, McKelvie, Ketchen, \& Chandler, 2009) that compromise decisionmaking. The literature on EO has found that organizational learning can positively influence the relationship between EO and performance (Real, Leal, \& Roldán, 2006; Wales et al., 2013b). Yet, recent examinations have failed to consider the impact of alternative approaches to organizational learning on the EO-performance relationship, thereby failing to understand nuances and contingencies in the triad between EO, learning modes, and firm performance. Absorptive capacity and organizational improvisation are two learning viewpoints that depict the classical debate of deliberate versus emergent action in strategy process research (Mintzberg \& Waters, 1985); capturing both deliberate, cumulative and repetitive learning action consistent with an absorptive capacity view (e.g. Bergh \& Lim, 2008; Berghman, Matthyssens, Streukens, \& Vandenbempt, 2013; Brauer, Mammen, \& Luger, 2014; Knoppen, Sáenz, \& Johnston, 2011), and conversely emergent, short-term and contemporaneous learning action consistent with an organizational improvisation view (Bergh \& Lim, 2008; Hadida, Tarvainen, \& Rose, 2014; Hodgkinson, Hughes, \& Arshad, 2016; Pina e Cunha, Clegg, \& Kamoche, 2012). More specifically, absorptive capacity as a deliberate rational process to organize, assimilate, and transform acquired knowledge (Hughes et al., 2014; Keh et al., 2007) implies great efforts to acquire and assimilate information to build on prior knowledge stocks (Cohen \& Levinthal, 1990), and is used as part of a deliberate sequence of opportunity identification, evaluation, and execution (e.g., Engelen et al., 2014). The majority of studies on absorptive capacity focus on deliberate learning and knowledge management (Robertson, Casali, \& 
Jacobson, 2012). Absorptive capacity then reflects a firm’s purposeful stock of knowledge resulting from flows of knowledge through an organization. Inherent to this definition is that the underlying learning processes have desirable outcomes (Knoppen et al., 2011). However, Hmieleski and Corbett (2006) note that given time pressure decisions when information for rational decision-making is inadequate, senior managers (as the orchestrators of a firm's EO) must rely on intuition to make decisions. When extended to collective action (Moorman \& Miner, 1998), an alternative mode of learning emerges through organizational improvisation (Miner, Bassoff, \& Moorman, 2001). Organizations can then learn by rapidly extemporizing and deploying information to quickly formulate new strategic decisions in the absence of process (Hmieleski, Corbett, \& Baron, 2013).

The difference between absorptive capacity and improvisation as two different learning modes presents an important strategic dilemma for SMEs: How should they use knowledge and information to unlock the benefits of EO? It is not enough to say that the features of EO by way of an emphasis on risk-taking, innovativeness, and proactiveness somehow ensure that firms continue to be malleable to changing environmental conditions. If it were, then firms that exhibit EO would never lose their way, which indeed is a fallacy (e.g., Short et al., 2009). SMEs must be able to effectively deviate from their plans in order to adapt to new and emerging environmental conditions (Hmieleski \& Ensley, 2004). Those firms bearing a sufficiently high EO will typically exhibit higher risk preferences shaping a planning horizon that sees complex and ambiguous situations much more positively than their less entrepreneurially oriented counterparts (e.g., Zahra, Wright, \& Abdelgawad, 2014).

Absorptive capacity and organizational improvisation are a basis for hypothesizing how learning might influence the actions associated with EO and (re)shape its effects on firm 
performance. With higher levels of EO, firms might improve performance by intensifying their information utilization efforts through their absorptive capacity. Such a learning mode builds specific knowledge stocks within the firm centered on improving existing activities. Nevertheless, while of value to younger and smaller firms (Hughes et al., 2014), they may prove detrimental as the firm ages and grows as its knowledge base becomes increasingly rigid to the 'tried-and-true'. SMEs might benefit from abandoning prior and repeat experiences in favor of emergent improvised decisions. Here the ability to extemporaneously learn and create and execute new plans in motion or in progress would appear important for entrepreneurially oriented firms to possess (Hmieleski \& Corbett, 2006) (e.g., as decisions emerge “on the spot” to address unexpected problems resulting in new approaches and new ideas that increase the power of the firm's EO along proactiveness and risk-taking dimensions). Thus, absorptive capacity and improvisation both appear to be important components of the EO-performance relationship, but their true compatibility with EO or the related performance implications of one learning mode over another is unclear.

Moreover, absorptive capacity and organizational improvisation are not technically mutually exclusive. Mintzberg and Waters (1985) posit that all viable strategies have deliberate and emergent qualities. However, theoretically, absorptive capacity and organizational improvisation are suggested to represent opposite and therefore alternative learning explanations (e.g., Bergh \& Lim, 2008; Miner et al., 2001; Winter, 2003). That their origins are inherently different points to tensions between the two modes (Levinthal \& Rerup, 2006) that for SMEs suggests an either/or trade-off. ${ }^{1}$ For instance, while the lessons from the past may help to shape the future (absorptive capacity), the potential downside is that firms may become locked into

\footnotetext{
${ }^{1}$ This is not to say that they cannot coexist. The answer to that question, however, requires an extensive theoretical treatment that is beyond the scope of this paper, and one that warrants its own separate treatment.
} 
past trajectories constraining any emergent action (Zahra et al., 2014). Absorptive capacity theoretically then may either increase the EO-performance relationship or squander it. To this end, Lumpkin and Dess (1996: 136) define EO as "the methods, practices, and decision-making styles managers use to act entrepreneurially," which implies an inevitable relationship between EO and organizational behaviors or activities that are seemingly compatible with EO (Anderson, Covin, \& Slevin, 2009). If EO is seen as a deliberate approach to strategy making in this respect (see Covin and Slevin, 1989), it may follow that a deliberate learning mode would be compatible to further the EO-performance relationship. But an emergent learning mode where planning and execution occur simultaneously has the potential to ignite the innovativeness, proactiveness, and risk-taking dimensions of EO in a way that creates high variability in firm performance.

There is little empirical evidence to support either assertion, and theoretical expectations about their effects depend on the mechanisms at play. For example, related studies find that for Singaporean SMEs EO increases the acquisition and use of marketing information but the use of that information itself partially mediates the EO-performance relationship (Keh et al., 2007). But for Swedish mid-sized manufacturing firms, a similar market orientation negatively moderates the EO-performance relationship (Morgan, Anokhin, Kretinin, \& Frishammar, 2015). For UK firms, learning orientation (not defined by learning mode) mediates the EO-performance relationship and more so for prospector-type firms (Wang, 2008). Among new ventures in Taiwan, knowledge creation mediates the EO-performance relationship (Li et al., 2009); and innovation speed mediates the EO-performance relationship, but whether organizational learning alters that contribution is not answered (Shan, Song, \& Ju, 2016). Moreover, Hughes and colleagues (2007) find that high levels of organizational learning (by collating information from external parties) compromise the performance contribution of EO among young and new venture 
firms. These existing studies are deficient however in that they do not explicitly examine the mediating or moderating effects specific learning modes may have on the EO-performance relationship. These studies depict inconsistent effects and this is likely due to learning mode - whether the firm is organized towards a deliberate, absorptive capacity focused learning mode or an emergent, improvisation focused learning mode—because the mode of learning has profound implications for how the EO-performance relationship may be augmented. Each learning mode changes the parameters for knowledge creation and knowledge use within the firm.

\section{Hypotheses}

Absorptive capacity and the EO-performance relationship

A firm's absorptive capacity defines the nature of its learning environment (Cohen \& Levinthal, 1990). Absorptive capacity represents an organizational process to use existing and related knowledge to recognize the value of new information, assimilate it, and transform it into learning artefacts maintained in organizational memory that can then be applied to commercial ends (Cohen \& Levinthal, 1990; Jansen, Van Den Bosch, \& Volberda, 2005; Lane, Koka, \& Pathak, 2006; Zahra \& George, 2002).

The greater the deliberate knowledge acquisition activity of the firm through its absorptive capacity then, the more options there are for understanding and acting on changes in the environment detected through the firm's EO. This can benefit innovation (Su, Ahlstrom, Li, \& Cheng, 2013) and firm performance (Liao, Welsch, \& Stoica, 2003) by assisting the process of sensemaking that is required when using an EO (Engelen et al., 2014). We, therefore, expect that higher levels of absorptive capacity positively moderates the EO-performance relationship 
because the ability of the firm to understand opportunities detected through its EO, apply novelty to these opportunities, and manage the risk associated with these opportunities increases under high absorptive capacity. Because of this, absorptive capacity ought to augment the relationship between EO and firm performance.

In theory, routines within the firm to organize and value knowledge newly acquired in the course of business activity helps it to embellish and refresh its knowledge stocks. In turn, this absorptive capacity allows the firm to transform and bundle knowledge into organizational learning in a form that can increase performance (Argote, McEvily, \& Reagans, 2003; Garud \& Nayyar, 1994; Kogut \& Zander, 1992). Stocks of knowledge, however, are only valuable when applied to existing business activity. As such, greater absorptive capacity could allow the firm to learn more effectively from the knowledge at hand to modify entrepreneurial actions accordingly to the benefit of performance. The value of absorptive capacity rests in the fact that greater stocks of knowledge built through it can directly inform better decision-making. Since absorptive capacity causes larger and richer stocks of knowledge to be purposefully built in the firm, this should both lessen knowledge deficits known to compromise returns to entrepreneurship (Short et al., 2009) and improve the learning architecture of the firm (Hughes et al., 2014).

Applied to the EO-performance relationship, absorptive capacity should enable better decisions to be made when acting entrepreneurially. Without it, there is a substantial risk that the forward-looking mindset to act in advance of competitors in circumstances that are not fully developed (proactive), applying novelty and innovation to commercialize fledgling opportunities (innovativeness), and dedicating resources to projects of uncertain outcomes (risk taking) becomes faulty and erroneous because of poor or inadequate knowledge throughout the firm. SMEs with a superior absorptive capacity can absorb better and more appropriate knowledge that 
overcomes their liabilities of smallness (Hughes et al., 2014) and should strengthen the EOperformance relationship (e.g., De Jong \& Freel, 2010; Gray, 2006; Liao et al., 2003; Wales et al., 2013b) by enabling it to make better and more informed decisions while acting entrepreneurially. Supporting this idea, De Clercq et al. (2010) find that the EO-performance relationship improves when a firm's social context supports knowledge exchange. Thus:

Hypothesis 1: Absorptive capacity moderates the relationship between entrepreneurial orientation and firm performance: when absorptive capacity is low the relationship is weaker but as absorptive capacity increases the relationship becomes stronger.

Absorptive capacity may also mediate the EO-performance relationship. A firm possessing and acting on an EO automatically generates large amounts of new information in the course of its activities (e.g., Zahra et al., 2014). As knowledge is generated through EO, routines for absorptive capacity are encouraged to form to better understand the knowledge it generates, assimilates, and applies to commercial ends (Cohen and Levinthal, 1990). In both theory and practice then, the actions a firm takes through its EO can inform its absorptive capacity and subsequent actions are themselves then filtered by the firm's absorptive capacity in the process of enacting EO towards commercial ends. This indicates a mediatory role for absorptive capacity in the EO-performance relationship.

A particularly robust EO can result in generating copious amounts of new knowledge because of its bias towards proactive, innovative, and risky activity. But that knowledge will carry uncertainty over its ultimate use and value. O’Reilly (1980) notes a paradox here: uncertainty demands more information for processing and learning but excessive information 
creates overload. In its worst case, little or no response to that knowledge creation is possible as organizational members become overwhelmed by the volume of information encountered through aggressive proactive, innovative, and risk-taking behavior. As decision-makers become increasingly incapable of filtering and managing large quantities of new information given their bounded rationality (Ocasio, 1997), the responses of decision-makers become suboptimal as they are unable to filter the abundance of information that confronts them (Hodgkinson, Hughes, \& Hughes, 2012). The solution lies in absorptive capacity as an intermediary mechanism in the process of translating performance gains from having developed an EO.

For EO to generate performance gains requires an absorptive capacity to be in place as an intermediary learning mode to make better use of the information and knowledge at hand (e.g., Kaufman, 1973). Knowledge generated through EO can feed into the firm's existing absorptive capacity, where learning becomes cumulative, self-reinforcing, and path dependent. This occurs because it is easier to recognize and evaluate knowledge in areas of prior familiarity (De Jong \& Freel, 2010). The returns to learning should then be higher. This relationship proposes that entrepreneurially oriented firms must continuously strive to develop their knowledge bases if they are to prosper and sustain their competitiveness (Wales et al., 2013a).

Absorptive capacity operates as a filtering mechanism to assimilate and retain knowledge that is deemed relevant to the lessons the organization has learnt from the past (e.g., competitor moves, changing customer trends, market opportunities and threats) or are directly applicable to its ongoing business activity (Hughes et al., 2014), transforming knowledge generated through EO into increasingly valuable knowledge stocks. As such, absorptive capacity acts as an intervening mechanism to positively affect firm performance. Using an absorptive capacity (to assimilate, organize, value, and transform acquired knowledge), a firm should be better placed to 
respond more effectively and swiftly to opportunities to the benefit of performance but only if the absorbed knowledge is the result of information generated from an EO. Thus:

Hypothesis 2: Absorptive capacity mediates the relationship between entrepreneurial orientation and firm performance.

\section{Improvisation and the EO-performance relationship}

Improvisation can explain how entrepreneurial firms deviate from strategic plans to respond to opportunities (or new circumstances) in the moment, as they arise. Improvisation may then enhance the execution of EO and its conversion into firm performance by affecting how it creates value. This is due to the unique characteristics of improvisation.

Improvisation has several characteristics that distinguish it from absorptive capacity:

"First, it has a reduced temporal gap between the planning and implementation of unique actions...Second, it applies to actions and decisions that are novel, or deviations from standard practices” (Bergh \& Lim, 2008: 599). We expect that an entrepreneurially oriented firm may witness superior firm performance when improvisation is also in place. For instance, Hmieleski and Ensley (2004) find that start-ups directed with a proclivity toward improvisational behavior tend to outperform less improvisational counterparts.

From a theoretical perspective, improvisation as a learning mode relies on an emergent, iterative process of extemporizing characterized by rapid information collection and its use to better perform decisions made under conditions of uncertainty and incomplete information (Hmieleski et al., 2013). Pina e Cunha, Vieira da Cunha, and Kamoche (1999: 317) posit that 'the higher the speed of the environment framing the organization, the higher the likelihood of it 
undertaking improvisational activities.' This suggests that improvisation is an important learning mode for SMEs in emerging or middle-income economies as they often face greater frequency of surprising events than their peers in developed economies (Zheng \& Mai, 2013). An EO can help a firm act positively when encountering hostile or complex environments (e.g., Covin \& Slevin, 1989; Miller, 1983) but improvisation may further augment this EO-performance relationship as it assists the firm to act in an impromptu and unrehearsed way, particularly when a prepared response is unlikely. Improvisation should also assist the firm to act more quickly and decisively when encountering new information about the environment through its proactive, innovative, and risk-taking behavior. In other words, when faced with change, improvisation can facilitate the shaping of novel responses to improve the EO-performance frontier further.

The learning actions associated with improvisation speak to situations where SMEs either lack knowledge due to their young age (Hughes et al., 2014) or cannot rely on a rational learning process owing to fast-paced or sudden change. Improvisation may then help the firm to benefit from its EO, particularly in times of rapid or sudden environmental change. This is reflected in the work of Garud and Karnoe (2001) who suggest that entrepreneurs meaningfully navigate a flow of events as they encounter them, highlighting concepts of time, bricolage, and mindfulness in this process, which are fundamental elements of improvisation (Crossan \& Hurst, 2006). Viewing improvisation as real-time support for opportunity identification, evaluation, and execution, it is likely that the EO-performance relationship will be positively moderated by organizational improvisation. Therefore, we hypothesize: 
Hypothesis 3: Organizational improvisation moderates the relationship between entrepreneurial orientation and firm performance: when organizational improvisation is low the relationship is weaker and as organizational improvisation increases the relationship becomes stronger.

Improvisation is a form of real-time learning to deal with unexpected events that can help or hurt the firm (Kyriakopoulos, 2011). Firms with a strong EO will enter new product markets aggressively and incur greater risks, requiring them to cope with more complex and changing circumstances that emerge rapidly and unexpectedly (Real et al., 2014). This can, therefore, create a demand for organizational improvisation to translate a firm's EO into actions that subsequently minimize any performance disruption caused by such environmental turbulence. The execution of EO may then invite or compel a need for improvisation as a means of managing the uncertainty and changeful conditions faced by the firm as a consequence of executing its EO. Improvisation should then mediate the effect of EO on firm performance: maintaining positive contributions to firm performance from $\mathrm{EO}$ would require a firm to make best use of its EO by having an improvising learning mode within the organization.

Improvisation enables in-motion modifications to actions to drive superior firm performance. It forgoes prior knowledge and the 'tried and true' so that action is extemporized with information collected as and when it is needed (Hmieleski et al., 2013). Thus, opportunities and circumstances generated through EO can be capitalized on in real time to the benefit of firm performance (Real et al., 2014), through improvisation. As such, organizational improvisation (as a mode of learning) is needed to act as an enabler to firms to capitalize on innovations, risk taking, and proactiveness such that improvisation mediates the EO-performance expectation: 
Hypothesis 4: Organizational improvisation mediates the relationship between entrepreneurial orientation and firm performance.

\section{Methods}

Data

We generated data through a mail survey of 150 Malaysian SMEs that were randomly selected from The Federation of Malaysian Manufacturers directory. Manufacturing SMEs were chosen using NAICS codes from the 31-33 Manufacturing categories. These firms face unpredictable and changing environments generating pressures to innovate, making these firms a highly appropriate research site in which to study our hypotheses. Following Sin (2010), we concentrated on Malaysia's southern Johor state as this is (a) a leading manufacturing hub in the East Asian region; (b) has the second largest concentration of manufacturing companies in Malaysia; and (c) we chose to hand deliver the survey to all sampled firms so as to improve response rates. The Owner, Chief Executive Officer, Chief Operating Officer, or Managing Director was selected as the key informant since these decision-makers are at the core of the strategic decision-making process and can provide the most reliable information regarding the firm's characteristics and performance.

Prior to administering the survey, we followed the directions for good practice provided by Podsakoff, MacKenzie, Lee, and Podsakoff (2003) and Spector and Brannick (1995) for limiting common method bias. Specifically, the measurement scales were placed in a random order; no idealized responses were implied, neutral wording was adopted for all items and no leading questions were used; questionnaire length was kept at a minimum; and detailed instructions for completion of the survey instrument were provided. Finally, guarantees of 
confidentiality and anonymity were provided to respondents to reduce respondent anxiety or answers based on social desirability. The questionnaire was pre-tested with a panel of scholars and managers to ensure acceptable face and content validity.

We followed a five-stage protocol to administer the survey. This consisted of prenotification, a full questionnaire pack hand delivered to the key informant of all sampled firms (to improve response rates), a first reminder letter, and a second reminder consisting of a full questionnaire pack, and subsequent telephone contact with non-respondents. Good practice regarding cover letter, questionnaire length, return postage, follow-ups, anonymity, lack of explicit deadlines, and university sponsorship were applied. These actions also aligned with Bednar and Westphal's (2006) guidance on improving response rates from survey research. A total of 122 responses were obtained. 11 respondent SMEs that had either ceased operations by the time we administered the survey or had missing data were eliminated from the analysis. The remaining 111 SMEs were subjected to data analysis. $60 \%$ of the respondent firms have been in existence for over 15 years and $66 \%$ of all respondents employ 50 employees or less. Only 5 firms employ more than 150 employees, but less than 200. This is consistent with the Malaysian Government definition of manufacturing SMEs as employing less than 200 employees. Nonresponse bias was examined through normal practice (Armstrong \& Overton, 1977) by statistically comparing responses provided by early and late respondents along all constructs contained in the model, which revealed no significant differences.

We tested for common method bias in several ways. First, we examined for common method bias using a Harman one-factor test in which all items were specified to load onto a single construct within a factor analysis (principal components with varimax rotation) (Podsakoff et al., 2003). The results demonstrate unacceptable fit and imply that common method concerns 
are not present as six factors are extracted with eigenvalues greater than 1; no one factor accounts for most of the variance; and, taken together, all of the extracted factors explain $69.4 \%$ of the variance. The largest factor identified only accounts for $14.4 \%$ of the total variance. When the analysis is specified to look for only one single factor (and not extract any number of factors with an eigenvalue greater than 1), this single factor accounts for only $29.3 \%$ of variance, with all measure items demonstrating poor factor loading onto this single construct with the exception of one item having a factor loading of 0.73 (loading range: 0.20 to 0.73 ). Second, we replicated this method in LISREL 8.8 using confirmatory factor analysis and specifying all items onto a single construct. If common method bias is present then a single factor will fit the data well. Once again, this assertion was rejected: $\chi^{2}=2028.78 ; \mathrm{df}=252 ; \chi^{2} / \mathrm{df}=8.05 ;$ RMSEA $=0.25$; $\mathrm{CFI}=0.56 ; \mathrm{NNFI}=0.51 ; \mathrm{GFI}=0.39$.

Third, after hypotheses testing, we examined again for the effects of common method bias by identifying a suitable marker variable and applying a partial correlation procedure (Podsakoff et al., 2003). ‘Achieving a work-life balance' was used as the marker variable as it is theoretically unrelated and uncorrelated ( $p \geq 0.10)$ to the constructs in the model. With this method, we partial out the correlations of this variable from the study variables. In doing so, we can examine whether the path loadings and relationships we found differ in any way. If significant changes were to occur, the presence of common method problems would seem likely. Examining the original results (Table 3) and the results obtained after using the partial correlation procedure (Appendix A) reveal no differences: no paths lose statistical significance, nor change direction, nor are there any large deviations in regression coefficients or $t$-values, and all moderation and mediation conclusions remain the same. While common method bias cannot be entirely excluded, we feel the sum total of the pre-survey measures taken and the post-hoc 
tests carried out render it unlikely that common method bias explains the results found in this work. Accordingly, the original hypotheses testing results are presented herein.

\section{Measures}

All measurement scales were drawn from previous studies. To gauge EO, measures used by Covin and Slevin (1989) were adopted. Measures of organizational improvisation were drawn from items used by Vera and Crossan (2005). Measures of absorptive capacity were adapted from a battery of items from Hodgkinson et al. (2012). To assess firm performance, measurement items by Hughes, Morgan, and Kouropalatis (2008) were used. A five-point Likerttype scale was used for all items. The precise wording of measurement items is presented in Table 1, along with the properties of these measurement items, as derived through principal components factor analysis using varimax rotation. The results show acceptable construct reliability with all values exceeding 0.70. Descriptive statistics are presented in Table 2.

--Table 1 about here--

--Table 2 about here--

We included firm age, firm size, senior manager tenure, and industry as control variables. First, firm age is accounted for. As a firm grows older, its stock of resources could be expected to grow in a manner that might facilitate both firm entrepreneurship and organizational learning (e.g., Cai, Hughes, \& Yin, 2014). In addition, firm age has been associated with a movement from learning advantages of newness towards greater degrees of knowledge filtration, although the merits of this may rely on absorptive capacity (Hughes et al., 2014). Second, firm size is associated with greater internal resource stocks, which might enable a firm to apply knowledge more readily to its entrepreneurial activities and towards performance. Firm size also suggests that a firm has accumulated larger internal knowledge stocks (Cohen \& Levinthal, 1990). Third, 
we control for senior manager tenure as it may have a direct influence on the entrepreneurial orientation of the firm. For example, Covin and Slevin (1989) define EO as the actions taken by top managers to shape an entrepreneurial strategic posture for their firm, and Lumpkin and Dess (1996: 136) define EO as 'the methods, practices, and decision-making styles managers use to act entrepreneurially'. In each case, the sensitivity of the firm's EO to senior manager tenure is theoretically plausible. Finally, we use a series of dummy variables to control for industry.

\section{Results}

Hypotheses were tested using multiple regression analysis and are bootstrapped for robustness. Table 3 presents the results. We begin by testing the direct path from EO to firm performance and confirm existing theory that this path is positive and significant $(\beta=0.22 ; p \leq 0.05)$. Next, we examine the moderation results of absorptive capacity (H1) and improvisation (H3), before reporting the mediation effects of the former (H2) and the latter (H4).

H1 specifies a moderation effect by absorptive capacity on the relationship between EO and firm performance. To test the moderation effects, we calculate multiplicative interaction terms. As normal, the constructs involved in the interaction terms are mean-centered to avoid potential problems of multicollinearity. Absorptive capacity does not have a significant moderating effect on the EO-performance relationship when we simply look at the multiplication term in regression $(\beta=0.01 ;$ n.s. $)$.

In conducting moderation analysis, it is possible that inflection points are so high that we miss out on finding true moderation effects if just looking at the $p$-value. As indicated by Krueger and Heck (2017: 1), the p-value in itself is not always a useful indicator: "Despite its general usefulness, the $p$-value cannot bear the full burden of inductive inference; it is but one of 
several heuristic cues available to the data analyst” (cf. Ziliak \& McCloskey, 2008). They go on to suggest that interpretation relies upon other estimates as relying on $p$-value alone may be misleading. Rather than just using regression to examine whether the effect is different from zero or not, this analysis utilized the Johnson-Neyman technique (Bauer \& Curran, 2005) to detect regions (or zones) of significance (Aiken \& West, 1991) and identify whether there are values of the moderator for which the effect on the EO-performance relationship is significant (Dawson, 2014). This is helpful in understanding the relationship between EO and performance, at different levels of the moderator; though ought to be interpreted with caution (Dawson, 2014).

Examination of Figures 2 and 3 and the results in Table 4 reveals that absorptive capacity at the upper-end of its values has a positive moderating effect on the EO-performance relationship and the conditional effect is only meaningful at high values $\geq-0.04$ (but most values fall well short of this, hence the non-significant regression result). Therefore, while H1 is unsupported by the raw regression statistics, scholars and managers can gain better understanding of the role of absorptive capacity: a zone of significance exists at the highest levels of absorptive capacity for a positive moderation effect but only at those highest levels.

--Table 3 and Table 4 about here---Figure 2 and Figure 3 about here--

H3 specifies a moderating effect by organizational improvisation on the EO-performance relationship. The results for organizational improvisation again show no moderating effect when looking at the interaction term results in Table 3 ( $\beta=-0.06$; n.s.), and further investigation of the conditional values show why this is the case. Referring to Table 4 and Figure 3, we can see that there is a region of significance (between $\geq-0.86$ and $\leq 0.97$ ) where a positive moderating effect exists and this region covers the mean and \pm 1 S.D. of improvisation, hence why in Figure 2, EO 
has a positive effect on performance regardless. In sum, regression results reveal that while the interaction effect is not significantly different from zero, there is once again a zone where improvisation can influence the EO-performance relationship. We cannot then wholly disregard the effects of improvisation: EO has a positive effect on performance regardless of improvisation as the multiplicative term is not significant; but we can see from the additional analysis that there can be a conditional effect in the mid-range.

$\mathrm{H} 2$ and $\mathrm{H} 4$ specify indirect relationships between EO and performance where absorptive capacity and organizational improvisation act as mediation mechanisms, respectively. We examine for mediation effects through the PROCESS method with bootstrapping (Hayes, 2013).

H2 is supported as the PROCESS mediation statistics for absorptive capacity reveals no zero values in the bootstrapped 95\% confidence interval range and the coefficients for the total, direct, and indirect effects are significant with standardized $b$ and $\kappa^{2}$ values confirming a mediation effect is present. The $b$ and $\kappa^{2}$ values can be interpreted as the indirect effect being about $12 \%$ to $13 \%$ (respectively) of the maximum indirect effect possible (Field, 2013).

We found no mediation effect through improvisation (H4). The indirect effect is statistically non-significant ( $\beta=0.01$; n.s.), the $95 \%$ confidence interval statistics under bootstrapping shows the indirect effect of improvisation can be less than zero, the standardized $b$ can be less than zero, and the $\kappa^{2}$ value can also equal zero. Reflecting on the results further, we do see that improvisation and firm performance are positively related under regression ( $\beta=0.35$; $p \leq 0.01$ ), indicating a direct effect on performance. The results for $\mathrm{H} 4$ imply that improvisation does not mediate the relationship between EO and performance, but rather acts independently as a means for Malaysian SMEs to increase firm performance.

Additional analysis 
We uncover further differences in learning modes between groups of high and low performing SMEs, by way of an ANOVA test, to determine whether differences exist in their relative levels of both absorptive capacity and improvisation. Performance groups were created at a split point of 3.5 (on a five-point scale). The results are shown in Table 5. Statistically significant differences are found between the high and low performing groups for both absorptive capacity and organizational improvisation. Low performing firms systematically exhibit lower levels of absorptive capacity $($ mean $=3.82)$ and improvisation $($ mean $=3.65)$ when compared to high performers (mean $=4.26,4.17$ respectively). These results imply that both absorptive capacity and improvisation are important for achieving high performance.

Taken together with the results for Hypotheses 1-4, the results as a whole demonstrate that high absorptive capacity is important to maintaining the EO-performance relationship due to its mediating effects. This EO-performance relationship is not contingent on the degree of organizational improvisation nor indirectly affected by it. However, the ANOVA results imply that SMEs gain from higher degrees of improvisation and this is borne out in the direct relationship between organizational improvisation and performance found under regression when examining for mediation effects. We color these inferences with the results of the conditional effect tests: upper-end levels of absorptive capacity can have a bearing on EO-performance while there are certain zones of improvisation values that can contribute also.

As modes of learning for SMEs then, there are merits to both approaches but favoring improvisation over absorptive capacity is risky. However, implementing organizational improvisation concurrently and not to the detriment of absorptive capacity appears sensible from the results given its own direct relationship with performance, but does not augment EO in itself. --Table 5 about here-- 


\section{Discussion}

This study was motivated by three key complementary problems in the research on EO and firm performance: first, to examine intermediate steps within the EO-performance relationship (e.g., Real et al., 2014; Wales et al., 2011, 2013b); second, to examine the distinct effects of absorptive capacity and organizational improvisation (Bergh \& Lim, 2008) on the EO-performance relationship (Anderson et al., 2009; Engelen et al., 2014; Miner et al., 2001); and third, to consider whether theoretical expectations about the EO-learning-performance triad hold when the research site is relocated away from advanced countries so as to better understand emerging and middle-income economies (Bruton et al., 2008, 2015; Kiss et al., 2012; Yu et al., 2014). Absorptive capacity does mediate the EO-performance relationship. While the moderation relationships appear to be insignificant for absorptive capacity and improvisation, this is ambiguous as there appears to be zone or regions of significance when absorptive capacity (at high levels) and improvisation (in certain mid-range values) have a meaningful impact. We caution though that such inferences are advisory only due to the non-significant regressions (Dawson, 2014).

\section{Contributions}

By disaggregating organizational learning into distinct learning modes, a far clearer picture of the EO-performance relationship emerges than is presented in the existing literature to date. Specifically, absorptive capacity represents a fundamental intermediate step between EO and firm performance. From a learning perspective, by enhancing knowledge assimilation, transfer, and use, absorptive capacity acts as an intervening factor in the effective delivery of EO and superior performance. EO cannot be separated from this crucial learning mode, therefore. Our 
work and findings thus contribute directly to resolving the call for theory generation on the intermediate steps in the EO-performance relationship (e.g. Real et al., 2014; Wales, 2016).

As our first contribution to theory, these findings enrich a learning-based view of EO. The value of EO relies on the mediation effects of absorptive capacity. There have been longstanding fears in the literature about the vulnerability of the EO-performance relationship to absorptive capacity as one distinct learning mode (e.g., Covin \& Lumpkin, 2011; Yu et al., 2014; Wales, 2016). A learning-based view of the EO-performance relationship accepts that EO itself can generate a wealth of information that in turn feeds the organizational learning of the firm by way of strengthening its absorptive capacity as an indirect route to improved firm performance). This speaks to the mediating effect of absorptive capacity on the EO-performance relationship. However, because EO itself sets a strategic posture that drives the firm to seek out and pursue opportunities and respond to them with innovative, proactive, and risk-bearing actions, the effectiveness of those actions likely relies on the ability of the firm to deploy its knowledge resources to make superior strategic decisions as part of the execution of EO. This speaks to the plausible moderating effect of absorptive capacity (at the highest levels) on the EO-performance relationship (Table 4; Figure 3). We caution though that more work is needed here to clarify this relationship. In sum, we contribute to refining a learning-based view of EO and the theoretical predictions about why some firms appear to gain more from their EO than others.

In contrast to theoretical expectations, however, organizational improvisation is unrelated to the EO-performance relationship. This is demonstrated by the non-significant mediation an moderation effects. Although a zone of significance exists for improvisation as a moderator (Table 4; Figure 3), we cannot discount the fact the hypothesis is unsupported as a whole. Moreover, our data shows that EO and improvisation do not even correlate, which reinforces the 
assertion that no relationship exists between them in the Malaysian SME context. This reveals that present theoretical treatment about the EO-learning-performance triad is incomplete, misunderstood, and misspecified as was a concern at the outset. The entrepreneurial context offers further evidence for theories of improvisation (Miner et al., 2001), but not as predicted when positioned in an emerging economy research site. Improvisation has been viewed as a deviation from existing knowledge in response to changing environments and as such would be assumed to benefit SMEs that typically experience turbulence (Hmieleski \& Ensley, 2004). We evidence such a direct performance benefit, but none whatsoever between EO and improvisation.

These findings lead us to refine our first contribution to theory. We validate theoretical expectations that EO can enhance learning-related firm processes (Covin \& Lumpkin, 2011), but we also show that relationships between EO and organizational outcomes can be explained by learning-related processes themselves. Specifically, we improve theory by demonstrating that such effects are reliant on absorption. Prior studies of EO and organizational learning (e.g., Hughes et al., 2007; Keh et al., 2007; Li et al., 2009; Wang 2008) have failed to consider the effects of alternative learning modes. Our discussion demonstrates the danger of this oversight in generating a theory capable of reliably predicting relationships among EO, learning, and firm performance. We contribute new knowledge to this effort by showing that absorptive capacity and organizational improvisation have very different learning-related processes at their core and both play very different roles in the EO-learning-performance connection. Our work, then, offers a more exact specification of theory on EO-learning-performance than what exists to date.

Our second contribution to theory relates to the question of how firms from emerging economies generate performance returns from EO. Theories, predictions, and causal mechanisms continue to originate from research developed in advanced economies (Kiss et al., 2012). We 
feared this would lead to faulty theoretical expectations and predictions about the value of learning modes in the EO-learning-performance relationship. Our concerns had some merit. For example, despite the intuitive appeal and theoretical expectation that improvisation ought to exhibit some causal and statistical dependence with EO, we find that it does not. We suggest then that the EO-learning-performance triad is sensitive to the type of learning mode. For example, Bergh and Lim (2008) indicated that distinctions may exist between absorptive capacity and organizational improvisation for firm performance. These distinctions extend to indirect effects with EO. We conclude that the execution of EO benefits from a methodical approach to learning characterized by its relationship with absorptive capacity. While organizational improvisation is not in itself detrimental to this approach, and offers its own contribution to firm performance, any investment in improvisation does not augment the EO-performance relationship either. These are important factors to consider in theorizing a learning-based view of EO.

Taken together, our theoretical contributions provide a basis to include a wider treatment of organizational learning in future predictions about EO and firm performance. This is particularly important because EO is “contingent upon the characteristics of a firm's strategic decision-making and information management process, that is, i.e., processes that broadly reflect [its wider] strategizing activity” (Covin, Green, \& Slevin, 2006: 59). Since the study of EO has been divorced from the study of organizational learning modes for so long, the field has failed to come to grips with how EO is subject to wider aspects of strategizing and learning activity in the firm, of which our study seeks to address.

In terms of practice, SMEs should seek to employ deliberate, cumulative, and repetitive learning consistent with an absorptive capacity since an inability to do so will weaken the potential performance gains possible from an EO (due to the mediation effect found); in fact, the 
higher the absorptive capacity the better for this relationship given the zone of significance reported We contend that managers should strongly consider maximizing the firm's absorptive capacity as a result, especially due to the zone of significance at the top end of absorptive capacity values for a moderation positive effect from it.

There appear to be no real downsides in our results for Malaysian SMEs to use an EO and improvisation together as pathways to superior performance, especially as higher improvisation is clearly shown in the ANOVA results for high performers and seems to benefit firm performance directly under regression. Thus, despite our empirical results disappointing our theoretical expectations, there appear to be dual benefits for Malaysian SMEs to adopt both EO and organizational improvisation.

Distinguishing between high performance and low performance groups allows the effects of the learning modes of absorptive capacity and improvisation to be made clearer in relation to the EO-performance relationship for managers. High performers are endowed with significantly higher levels of absorptive capacity and improvisation relative to low performers. So, rather than viewing absorptive capacity and improvisation as alternative learning modes (Bergh \& Lim, 2008), suggesting that SMEs may favor one over the other, it may be better to balance these opposite learning viewpoints. Doing so can enhance the EO-performance relationship through absorptive capacity while also exploiting the direct effect of organizational improvisation on performance. That is, rather than saying that managers must utilize one learning mode or the other, they can use both (Dunbar \& Ahlstrom, 1995). How managers are able to strike a balance between the two learning modes, however, requires a clearer understanding of the nuances and interactions that may exist in their implementation as well as the idiosyncrasies of emerging 
economies' institutional environments and how these affect firm behavior and performance (Ahlstrom, Levitas, Hitt, Dacin, \& Zhu, 2014; Lee, Yamakawa, Peng, \& Barney, 2011). Limitations and future research Limitations to our findings do exist. First, our results cannot be generalized to contexts far outside that considered here—manufacturing SMEs in an emerging middle-income economy. In distinguishing between different types of emerging economies, future research can extend the usefulness of our findings for the form and effect of EO in specific types of emerging economies (Zahra et al., 2014). Second, this study was based on a cross-sectional design and does not allow causality to be asserted from the data. We suggest a longitudinal study would be an appropriate next step. Third, judgments about the constructs of interest, although qualified, have been reported by a single informant at one point in time. Although no material common method problems were found, data generated from a greater number of observations from multiple informants and across multiple moments in time should be the ambition of future studies.

Fourth, subjective evaluations are used. Still, while objective measures of performance are considered 'more valid' than subjective ones, managerial perceptions have been found to deviate minimally from objective indicators of performance (Kyriakopoulos, 2011). Indeed, it would be expected that senior officers such as CEOs have an accurate grasp of the performance of their firm given the almost constant pressures on them from investors and stakeholders as well as governance nuances in emerging economies (Young, Peng, Ahlstrom, \& Bruton, 2003). In addition, the validity of objective measures relies enormously on their accuracy as proxies for constructs of interest. Fifth, we find non-significant regression results for the moderators and improvisation as a mediator, despite theoretical indications that such relations would exist. While the Johnson-Neyman diagnostic statistics clearly show a zone of significance, there may be 
contextual or strategic factors not considered here that need investigation. For instance, are they non-significant due to the country or cultural context? Are there other intervening learning or knowledge management processes at play? There are clear avenues for future research arising from these results.

Beyond this, three clear avenues for future research emerge. First, organizational improvisation appears to sit in parallel to EO, likely because improvisation involves spontaneous action outside of the formal planning cycle (Vera \& Crossan, 2005). This may speak to notions of bounded rationality contained in management theories relevant to understanding firms’ EO. Improvisational behaviors such as creativity, spontaneity, and intuition would appear to link with EO dimensions of innovativeness, proactiveness, and risk-taking. This explains why improvisation and EO appear to be compatible even though we could find no significant findings for an intermediate effect by improvisation in the relationship between EO and firm performance. Given the lack of attention to improvisation in the entrepreneurship literature, far greater theorization now seems to be needed to distil improvisation within the entrepreneurship process.

Second, indeed work on improvisation in the field of entrepreneurship is in a fledgling state and our findings offer a timely theoretical contribution to this debate. The difference between our empirical observations and theoretical expectations shows that scholars need to theorize what organizational improvisation means for entrepreneurship in firms and also what role it should play in a strategic posture driven by EO. While improvisation does not mediate the EO-performance relationship, it does itself offer a direct effect on firm performance and does so without weakening the EO-performance relationship.

Third, reflecting on Table 2, we observe that absorptive capacity and improvisation positively correlate. An existing absorptive capacity may provide a knowledge reservoir that 
managers may draw upon when relying on intuitive judgments or to make improvised decisions. Contrary to expectations (e.g., Bergh \& Lim, 2008), perhaps one may complement the other. The extent to which we can rely on this suggestion, however, is contingent upon further research. This offers a promising basis for future research to theorize and examine the relationship between absorptive capacity and organizational improvisation, which is important as researchers seek to better understand entrepreneurial-driven growth, particularly in emerging economies (Aghion, Akcigit, \& Howitt, 2014; Bruton et al., 2008; Chen, Chang, \& Bruton, 2017).

\section{Conclusion}

This paper sought to address the question of the importance of entrepreneurial orientation for emerging economy firms. The answer we found suggests that performance returns are strongly achieved through the firms’ absorptive capacity. Moreover, this research introduces an assessment of the intermediate steps in the EO-performance relationship by investigating the moderating and mediating effects of two key alternative learning modes: absorptive capacity and improvisation. The findings suggested that performance gains from an EO are strengthened through both the moderating and mediating effects of absorptive capacity. In contrast, the findings suggest that organizational improvisation is actually not an intermediate step in the EOperformance relationship, but rather confers its own separate benefits with respect to firm performance. Moreover, SMEs with high levels of absorptive capacity and improvisation achieve higher levels of performance relative to SMEs with low levels of both absorptive capacity and organizational improvisation. This paper thus adds to the growing calls by researchers and managers for robust evidence and the identification of key moderators and specific mediation mechanisms to clarify the process of how vital concepts such as EO actually function (Ahlstrom, 
2010; Tang \& Tang, 2012). And in particular, how these might function in different types of emerging economies where building this understanding is especially vital (Bruton et al., 2008;

Zahra et al., 2014).

\section{References}

Aghion, P., Akcigit, U., \& Howitt, P. 2014. What do we learn from Schumpeterian Growth Theory? In P. Aghion \& S. Durlauf (Eds.). Handbook of Economic Growth, Volume 2, 515-563. Kidlington, UK: North Holland.

Ahlstrom, D. 2010. Publishing in the Asia Pacific Journal of Management. Asia Pacific Journal of Management, 27(1): 1-8.

Ahlstrom, D., Levitas, E., Hitt, M. A., Dacin, M. T., \& Zhu, H. 2014. The three faces of China: Strategic alliance partner selection in three ethnic Chinese economies. Journal of World Business, 49(4): 572-585.

Aiken, L.S. \& West, S.G. 1991. Multiple regression: Testing and interpreting interactions. Newbury Park, London: Sage.

Anderson, B. S., Covin, J. G., \& Slevin, D. P. 2009. Understanding the relationship between entrepreneurial orientation and strategic learning capability: An empirical investigation. Strategic Entrepreneurship Journal, 3(3): 218-240.

Argote, L., McEvily, B., \& Reagans, R. 2003. Managing knowledge in organizations: An integrative framework and review of emerging themes. Management Science, 49(4): 571582.

Armstrong, J. S. \& Overton, T. S. 1977. Estimating non-response bias in mail surveys. Journal of Marketing Research, 14(August): 396-403.

Bauer, D. J. \& Curran, P. J. 2005. Probing interactions in fixed and multilevel regression: Inferential and graphical techniques. Multivariate Behavioral Research, 40(3): 373-400.

Bednar, M. K. \& Westphal, J. D. 2006. Surveying the corporate elite: Theoretical and practical guidance on improving response rates and response quality in top management survey questionnaires. In D.J. Ketchen \& D.D. Bergh (Eds.), Research Methodology in Strategy and Management: 37-55. Bingley, UK: Emerald. 
Bergh, D. D. \& Lim, E. N. K. 2008. Learning how to restructure: Absorptive capacity and improvisational views of restructuring actions and performance. Strategic Management Journal, 29(6): 593-616.

Berghman, L., Matthyssens, P., Streukens, S., \& Vandenbempt, K. 2013. Deliberate learning mechanisms for stimulating strategic innovation capacity. Long Range Planning, 46(1): 39-71.

Brauer, M., Mammen, J., \& Luger, J. 2014. Sell-Offs and firm performance a matter of experience? Journal of Management. doi: 0149206314552452.

Bruton, G. D., Ahlstrom, D., \& Oblój, K. 2008. Entrepreneurship in emerging economies: Where are we today and where should the research go in the future? Entrepreneurship: Theory and Practice, 32(1): 1-14.

Bruton, G. D., Ahlstrom, D., \& Si, S. 2015. Entrepreneurship, poverty, and Asia: Moving beyond subsistence entrepreneurship. Asia Pacific Journal of Management, 32(1): 1-22

Cai, L., Hughes, M., \& Yin, M. 2014. The relationship between resource acquisition methods and firm performance in Chinese new ventures: The intermediate effect of learning capability. Journal of Small Business Management, 52: 365-389

Chen, J., Chang, A. Y., \& Bruton, G. D. 2017. Microfinance: Where are we today and where should the research go in the future? International Small Business Journal, 35(6):

Cohen, W. M. \& Levinthal, D. A. 1990. Absorptive capacity: A new perspective on learning and innovation. Administrative Science Quarterly, 35(1): 128-152.

Covin, J. G. \& Lumpkin, G. T. 2011. Entrepreneurial orientation theory and research: Reflections on a needed construct. Entrepreneurship Theory and Practice, 35(5): 855872.

Covin, J. G. \& Miller, D. 2014. International entrepreneurial orientation: Conceptual considerations, research themes, measurement issues, and future research directions. Entrepreneurship Theory and Practice, 38(1): 11-44.

Covin, J. G. \& Slevin, D. P. 1988. The influence of organization structure ion the utility of an entrepreneurial top management style. Journal of Management Studies, 25(3): 217-234.

Covin, J. G. \& Slevin, D. P. 1989. Strategic management of small firms in hostile and benign environments. Strategic Management Journal, 10(1): 75-87. 
Covin, J. G., Green, K. M., \& Slevin, D. P. 2006. Strategic process effects on the entrepreneurial orientation-sales growth rate relationship. Entrepreneurship Theory and Practice, 30(1): 57-81.

Crossan, M. M. \& Hurst, D. K. 2006. Strategic renewal as improvisation: Reconciling the tension between exploration and exploitation. Advances in Strategic Management, 23: 273-298.

Crossan, M. \& Sorrenti, M. 1997. Making sense of improvisation. Advances in Strategic Management, 14: 155-180.

Dawson, J. F. 2014. Moderation in management research: What, why, when, and how. Journal of Business and Psychology, 29(1): 1-19.

De Jong, J. P. \& Freel, M. 2010. Absorptive capacity and the reach of collaboration in high technology small firms. Research Policy, 39(1): 47-54.

De Clercq, D., Dimov, D., \& Thongpapanl, N. T. 2010. The moderating impact of internal social exchange processes on the entrepreneurial orientation-performance relationship. Journal of Business Venturing, 25(1): 87-103.

Dunbar, R. L. M. \& Ahlstrom, D. 1995. Seeking the institutional balance of power: Avoiding the power of a balanced view. Academy of Management Review, 20(1): 171-192.

Engelen, A., Kube, H., Schmidt, S. \& Flatten, T. C. 2014. Entrepreneurial orientation in turbulent environments: The moderating role of absorptive capacity. Research Policy, 43(8): 1353-1369.

Field, A. 2013. Discovering Statistics using IBM SPSS Statistics. London: Sage.

Garud, R. \& Karnoe, P. 2001. Path Dependence and Creation. Mahwah, NJ: Lawrence Erlbaum Associates, Inc.

Garud, R. \& Nayyar, P. R. 1994. Transformative capacity: Continual structuring by intertemporal technology transfer. Strategic Management Journal, 15(5): 365-385.

Gerber, M. E. 2004. The E-Myth revisited: Why most small businesses don't work and what to do about it. New York: HarperCollins.

Gray, C. 2006. Absorptive capacity, knowledge management and innovation in entrepreneurial small firms. International Journal of Entrepreneurial Behavior \& Research, 12(6): 345360. 
Hadida, A. L., Tarvainen, W., \& Rose, J. 2014. Organizational improvisation: A consolidating review and framework. International Journal of Management Reviews, 17(4): 437-459.

Hayes, A.F. 2013. Introduction to Mediation, Moderation, and Conditional Process Analysis: A Regression-Based Approach. New York, NY: Guilford Press.

Hmieleski, K. M. \& Corbett, A. C. 2006. Proclivity for improvisation as a predictor of entrepreneurial intentions. Journal of Small Business Management, 44(1): 45-63.

Hmieleski, K. M., Corbett, A. C., \& Baron, R. A. 2013. Entrepreneurs’ improvisational behavior and firm performance: A study of dispositional and environmental moderators. Strategic Entrepreneurship Journal, 7(2): 138-150.

Hmieleski, K. M. \& Ensley, M. D. 2004. An investigation of improvisation as a strategy for exploiting dynamic opportunities. In W. D. Bygrave et al. (Eds.), Frontiers of Entrepreneurship Research: 596-606. Babson Park, MA: Babson College.

Hodgkinson, I. R., Hughes, P., \& Arshad, D. 2016. Strategy development: Driving improvisation in Malaysia. Journal of World Business, 51(3): 379-390.

Hodgkinson, I. R., Hughes, P., \& Hughes, M. 2012. Absorptive capacity and market orientation in public service provision. Journal of Strategic Marketing, 20(3): 211-229.

Hughes, M., Hughes, P., \& Morgan, R. E. 2007. Exploitative learning and entrepreneurial orientation alignment in emerging young firms: Implications for market and response performance. British Journal of Management, 18(4): 359-375.

Hughes, M. \& Morgan, R.E. 2007. Deconstructing the relationship between entrepreneurial orientation and business performance at the embryonic stage of firm growth. Industrial Marketing Management, 36(5): 651-661.

Hughes, M., Morgan, R.E., Ireland, R.D., \& Hughes, P. 2014. Social capital and learning advantages: A problem of absorptive capacity. Strategic Entrepreneurship Journal, 8(3): 214-233.

Hughes, P., Morgan, R.E., \& Kouropalatis, Y. 2008. Market knowledge diffusion and business performance. European Journal of Marketing, 42(11/12): 1372-1395.

Jansen, J. J., Van Den Bosch, F. A., \& Volberda, H. W. 2005. Managing potential and realized absorptive capacity: How do organizational antecedents matter? Academy of Management Journal, 48(6): 999-1015.

Kaufman, H. 1973. Administrative feedback. Washington, D.C: Brookings. 
Keh, H. T., Nguyen, T. T. M., \& Ng, H. P. 2007. The effects of entrepreneurial orientation and marketing information on the performance of SMEs. Journal of Business Venturing, 22(4): 592-611.

Kiss, A. N., Danis, W. M., \& Cavusgil, S. T. 2012. International entrepreneurship research in emerging economies: A critical review and research agenda. Journal of Business Venturing, 27(2): 266-290.

Knoppen, D., Sáenz, M. J., \& Johnston, D. A. 2011. Innovations in a relational context: Mechanisms to connect learning processes of absorptive capacity. Management Learning, 42(4): 419-438.

Kogut, B. \& Zander, U. 1992. Knowledge of the firm, combinative capabilities, and the replication of technology. Organization Science, 3(3): 383-397.

Krueger, J. I. \& Heck, P. R. 2017. The heuristic value of p in inductive statistical inference. Frontiers in Psychology, 8(908): 1-16.

Kyriakopoulos, K. 2011. Improvisation in product innovation: The contingent role of market information sources and memory types. Organization Studies, 32(8): 1051-1078.

Lane, P. J., Koka, B. R., \& Pathak, S. 2006. The reification of absorptive capacity: A critical review and rejuvenation of the construct. Academy of Management Review, 31(4): 833863.

Lee, S-H., Yamakawa, Y., Peng, M. W., \& Barney, J. B. 2011. How do bankruptcy laws affect entrepreneurship development around the world? Journal of Business Venturing, 26: 505520.

Levinthal, D.A. \& Rerup, C. 2006. Crossing an apparent chasm: Bridging mindful and lessmindful perspectives on organizational learning. Organization Science, 17(4): 502-513.

Li, Y.-H., Huang, J. W., \& Tsai, M. T. 2009. Entrepreneurial orientation and firm performance: The role of knowledge creation process. Industrial Marketing Management, 38: 440-449.

Liao, J., Welsch, H., \& Stoica, M. 2003. Organizational absorptive capacity and responsiveness: An empirical investigation of growth-oriented SMEs. Entrepreneurship Theory and Practice, 28(1): 63-85.

Lumpkin, G. T. \& Dess, G. G. 1996. Clarifying the entrepreneurial orientation construct and linking it to performance. Academy of Management Review, 21(1): 135-172. 
Miller, D. 1983. The correlates of entrepreneurship in three types of firms. Management Science, 29(7): 770-791.

Miner, A. S., Bassof, P., \& Moorman, C. 2001. Organizational improvisation and learning: A field study. Administrative Science Quarterly, 46(2): 304-337.

Mintzberg, H. \& Waters, J. A. 1985. Of strategies, deliberate and emergent. Strategic Management Journal, 6(3), 257-272.

Moorman, C. \& Miner, A. S. 1998. Organizational improvisation and organizational memory. Academy of Management Review, 23(4): 698-723.

Morgan, T., Anokhin, S., Kretinin, A., \& Frishammar, J. 2015. The dark side of the entrepreneurial orientation and market orientation interplay: A new product development perspective. International Small Business Journal, 33(7): 731-751.

Ocasio, W. 1997. Towards an attention-based view of the firm. Strategic Management Journal, 18(S1): 403-404.

O'Reilly, C. A. 1980. Individuals and information overload in organizations: Is more necessarily better? Academy of Management Journal, 23(4): 684-696.

Peng, M. W. 2001. How entrepreneurs create wealth in transition economies. Academy of Management Executive, 15(1): 95-108.

Pina e Cunha, M., Clegg, S. R., \& Kamoche, K. 2012. Improvisation as "real time foresight". Futures, 44(3): 265-272.

Pina e Cunha, M., Vieira da Cunha, J., \& Kamoche, K. 1999. Organizational improvisation: What, when, how and why. International Journal of Management Reviews, 1(3): 299-341.

Podsakoff, P. M., MacKenzie, S. B., Lee, J. Y., \& Podsakoff, N. P. 2003. Common method biases in behavioral research: A critical review of the literature and recommended remedies. Journal of Applied Psychology, 88(5): 879.

Real, J. C., Leal, A., \& Roldán, J. L. 2006. Information technology as a determinant of organizational learning and technological distinctive competencies. Industrial Marketing Management, 35(4): 505-521.

Real, J. C., Roldán, J. L., \& Leal, A. 2014. From entrepreneurial orientation and learning orientation to business performance: Analysing the mediating role of organizational learning and the moderating effects of organizational size. British Journal of Management, 25(2): 186-208. 
Rigg, J., Promphaking, B., \& Le Mare, A. 2014. Personalizing the middle-income trap: An intergenerational migrant view from rural Thailand. World Development, 59: 184-198.

Robertson, P. L., Casali, G. L., \& Jacobson, D. 2012. Managing open incremental process innovation: Absorptive capacity and distributed learning. Research Policy, 41(5), 822832.

Shan, P., Song, M., \& Ju, X. 2016. Entrepreneurial orientation and performance: Is innovation speed a missing link? Journal of Business Research, 69(2): 683-690.

Shane, S. A. 2010. The illusions of entrepreneurship: The costly myths that entrepreneurs, investors, and policy makers live by. New Haven, CT: Yale University Press.

Short, J. C., McKelvie, A., Ketchen, D. J., \& Chandler, G. N. 2009. Firm and industry effects on firm performance: A generalization and extension for new ventures. Strategic Entrepreneurship Journal, 3(1): 47-65.

Sin, K. C. 2010. The Success Stories of Malaysian SMEs in Promoting and Penetrating Global Markets through Business Competitiveness Strategies. Copenhagen Business School, Denmark: Asia Research Centre.

Spector, P. E. \& Brannick, M. T. 1995. The nature and effects of method variance in organizational research. In C. L. Cooper and I. T. Robertson (Eds.), International Review of Industrial and Organizational Psychology, 10: 249-274. Chichester, UK: John Wiley.

Su, Z., Ahlstrom, D., Li, J., \& Cheng, D. 2013. Knowledge creation capability, absorptive capacity, and product innovativeness. $R \& D$ Management, 43(5): 473-485.

Tang, Z. \& Tang, J. 2012. Entrepreneurial orientation and SME performance in China's changing environment: The moderating effects of strategies. Asia Pacific Journal of Management, 29(2): 409-431

Vera, D. \& Crossan, M. 2005. Improvisation and innovative performance in teams. Organization Science, 16(3): 203-224.

Wales, W. J. 2016. Entrepreneurial orientation: A review and synthesis of promising research directions. International Small Business Journal, 34(1): 3-15.

Wales, W. J., Monsen, E., \& McKelvie, A. 2011. The organizational pervasiveness of entrepreneurial orientation. Entrepreneurship Theory and Practice, 35(5): 895-923. 
Wales, W. J., Parida, V., \& Patel, P. C. 2013a. Too much of a good thing? Absorptive capacity, firm performance, and the moderating role of entrepreneurial orientation. Strategic Management Journal, 34(5): 622-633.

Wales, W. J., Patel, P. C., Parida, V., \& Kreiser, P. M. 2013b. Nonlinear effects of entrepreneurial orientation on small firm performance: The moderating role of resource orchestration capabilities. Strategic Entrepreneurship Journal, 7(2): 93-121.

Wang, C. L. 2008. Entrepreneurial orientation, learning orientation, and firm performance. Entrepreneurship Theory and Practice, 32(4): 635-656.

Wang, L. C., Ahlstrom, D., Nair, A., \& Hang, R. Z. 2008. Creating globally competitive and innovative products: China's next Olympic challenge. SAM Advanced Management Journal, 73(3): 4-15.

Winter, S. G., 2003. Understanding dynamic capabilities. Strategic Management Journal, 24(10): 991-995.

Xavier, J. A. \& Ahmad, Z. U. 2012. Proposed scholarly research agenda for transforming Malaysia into a model developing nation. International Journal of Public Sector Management, 25(3): 231-243.

Young, M. N., Peng, M. W., Ahlstrom, D., \& Bruton, G. D. 2003. Principal-principal agency. Web Journal of Chinese Management Review, 6(1): 18-45.

Yu, B., Hao, S., Ahlstrom, D., Si, S., Liang, D. 2014. Entrepreneurial firms’ network competence, technological capability, and new product development performance. Asia Pacific Journal of Management, 31(3): 687-704

Zahra, S. A. \& George, G. 2002. Absorptive capacity: A review, reconceptualization, and extension. Academy of Management Review, 27(2): 185-203.

Zahra, S. A. \& Wright, M. 2011. Entrepreneurship’s next act. Academy of Management Perspectives, 25(1): 67-83.

Zahra, S. A., Wright, M., \& Abdelgawad, S. G. 2014. Contextualization and the advancement of entrepreneurship research. International Small Business Journal, 32(5): 479-500.

Zheng, Y. \& Mai, Y. 2013. A contextualized transactive memory system view on how founding teams respond to surprises: Evidence from China. Strategic Entrepreneurship Journal, 7(3): 197-213. 
Ziliak, S. T. \& McCloskey, D. N. 2008. The cult of statistical significance: How the standard error costs us jobs, justice, and lives. Ann Arbor, MI: University of Michigan Press. 


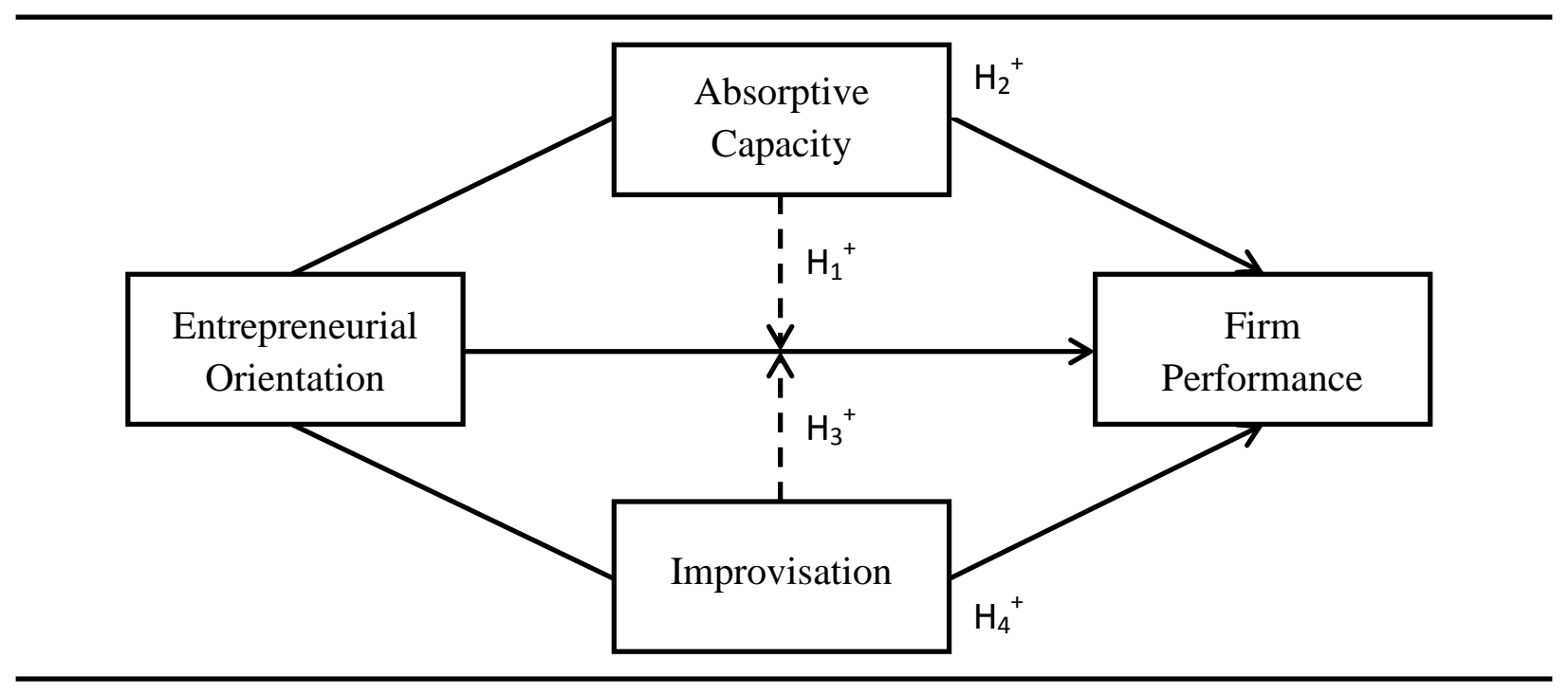

Figure 1. Conceptual framework
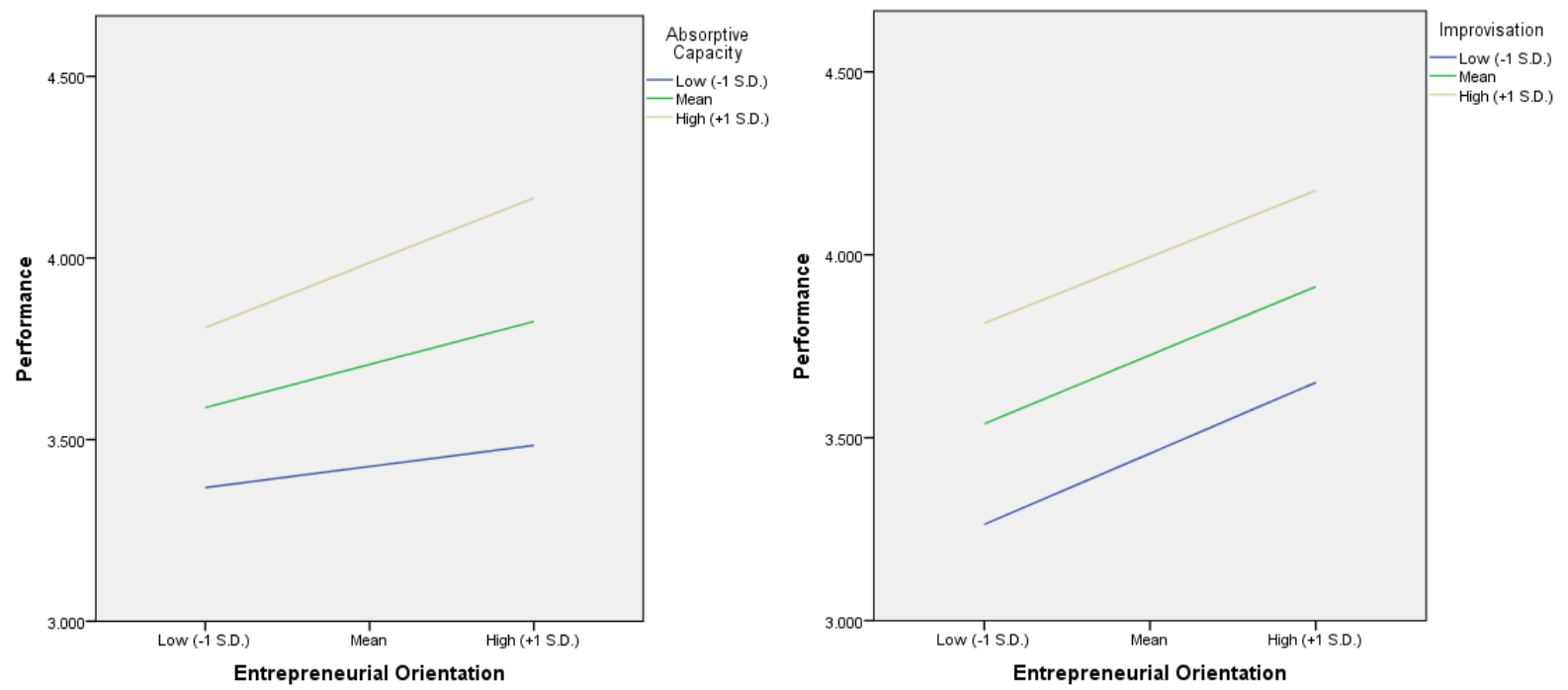

Figure 2. Slope Plots for Moderation Effects of Absorptive Capacity and Improvisation 

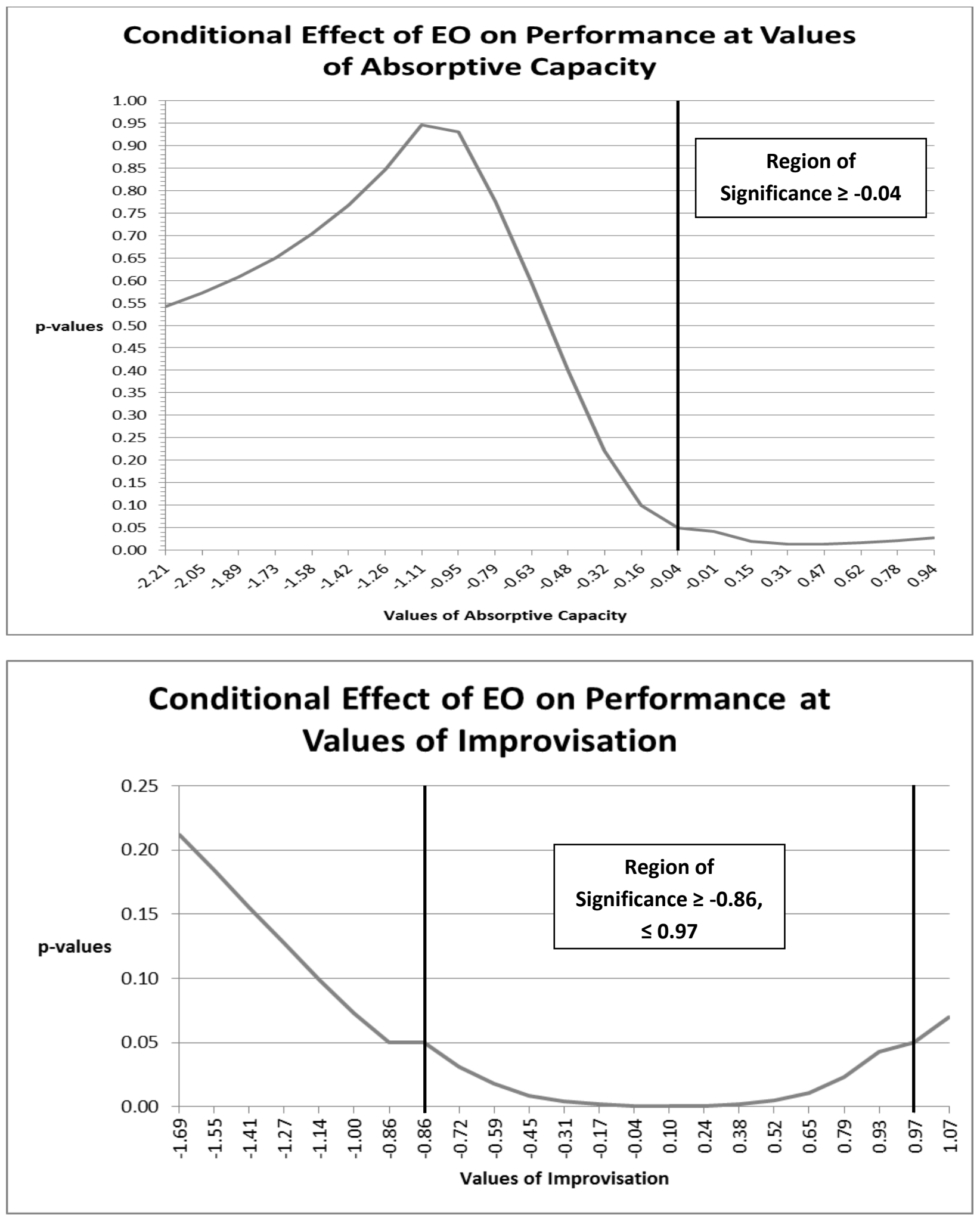

Figure 3. Conditional Effect of EO and Performance at Values of the Moderators 


\section{Table 1. Measurement Item Properties}

\begin{tabular}{|c|c|c|}
\hline Construct & Measurement Item & $\begin{array}{l}\text { Factor } \\
\text { Loading }\end{array}$ \\
\hline $\begin{array}{l}\text { Entrepreneurial } \\
\text { Orientation }(\alpha= \\
0.90)\end{array}$ & $\begin{array}{l}\text {... a strong emphasis on } \mathrm{R} \& \mathrm{D} \text {, technological leadership, and innovations } \\
\text {...very many new lines of products } \\
\text {...changes in product lines have usually been quite dramatic } \\
\text {...typically initiates actions which competitors then respond to } \\
\text {...is very often the first business to introduce new products, operating } \\
\text { technologies, administrative techniques } \\
\text {..typically adopts a very competitive, "undo-the-competitors" posture } \\
\text {... a strong proclivity for high risk projects (with chances of very high return). } \\
\text {... owing to the nature of the environment, bold, wide-ranging acts are necessary } \\
\text { to achieve the company's objective } \\
\text {...typically adopts a bold, aggressive posture in order to } \\
\text { maximize the probability of exploiting potential opportunities }\end{array}$ & $\begin{array}{l}.80 \\
.72 \\
.84 \\
.83\end{array}$ \\
\hline $\begin{array}{l}\text { Absorptive Capacity } \\
(\alpha=0.83)\end{array}$ & $\begin{array}{l}\text { We design ways to share knowledge and enhance learning throughout the } \\
\text { organization } \\
\text { We take on the roles of coaching, mentoring, and facilitating learning } \\
\text { We have accessible systems for collecting internal and external information } \\
\text { Systems and structures exists to ensure that important knowledge is coded, } \\
\text { stored, and made available to those who need and can use it } \\
\text { Cross-functional teams are used to transfer important learning across groups, } \\
\text { departments and divisions } \\
\text { We continue to develop new strategies and mechanisms for sharing learning } \\
\text { throughout the organization } \\
\text { We support specific areas, units, and projects that generate knowledge by } \\
\text { providing people with learning opportunities }\end{array}$ & $\begin{array}{l}.65 \\
.68 \\
.66 \\
.58 \\
.75 \\
.81 \\
.76\end{array}$ \\
\hline $\begin{array}{l}\text { Organizational } \\
\text { Improvisation }(\alpha= \\
\text { 0.73) }\end{array}$ & $\begin{array}{l}\text { We deal with unanticipated events on the spot } \\
\text { We respond in the moment to unexpected problems } \\
\text { We try new approaches to problems } \\
\text { We take risks in terms of producing new ideas in doing the job }\end{array}$ & $\begin{array}{l}.73 \\
.71 \\
.81 \\
.73\end{array}$ \\
\hline $\begin{array}{l}\text { Firm Performance ( } \alpha \\
=0.85)\end{array}$ & $\begin{array}{l}\text { Return on sales } \\
\text { Net profit } \\
\text { Market share } \\
\text { Return on investment }\end{array}$ & $\begin{array}{l}.74 \\
.87 \\
.86 \\
.85\end{array}$ \\
\hline
\end{tabular}




\section{Table 2. Correlation matrix and descriptive statistics}

\begin{tabular}{|c|c|c|c|c|c|}
\hline & & 1 & 2 & 3 & 4 \\
\hline 1 & Entrepreneurial Orientation & --- & & & \\
\hline 2 & Absorptive Capacity & $0.30 * *$ & --- & & \\
\hline 3 & Organizational Improvisation & 0.06 & $0.35 * *$ & --- & \\
\hline 4 & Firm Performance & $0.32 * *$ & $0.46^{* *}$ & $0.44 * *$ & --- \\
\hline \multicolumn{2}{|c|}{ Mean } & 3.85 & 4.05 & 3.93 & 3.73 \\
\hline \multicolumn{2}{|c|}{ SD } & 1.09 & 0.53 & 0.63 & 0.64 \\
\hline
\end{tabular}

Notes: ** Significant at 0.01 level; SD: Standard deviation. 
Table 3. Regression Results

\begin{tabular}{|c|c|c|c|}
\hline \multicolumn{4}{|l|}{ MODERATION ANALYSIS } \\
\hline Variables & Model 1 & $\begin{array}{c}\text { Regression Models } \\
\text { Model } 2\end{array}$ & Model 3 \\
\hline \multicolumn{4}{|c|}{ Control and Industry Dummy Variables } \\
\hline \multirow{2}{*}{ Tenure } & $0.01(0.06)$ & $0.02(0.24)$ & $0.03(0.32)$ \\
\hline & {$[-0.14,0.13]$} & {$[-0.11,0.12]$} & {$[-0.09,0.14]$} \\
\hline \multirow[t]{2}{*}{ Firm Age } & $0.13(1.09)$ & $0.11(1.11)$ & $0.10(1.00)$ \\
\hline & {$[-0.04,0.17]$} & {$[-0.04,0.16]$} & {$[-0.05,0.15]$} \\
\hline \multirow[t]{2}{*}{ Firm Size } & $0.08(0.67)$ & $0.00(0.00)$ & $0.00(0.00)$ \\
\hline & {$[-0.18,0.33]$} & {$[-0.26,0.19]$} & {$[-0.30,0.24]$} \\
\hline \multirow[t]{2}{*}{ Industry 1} & $0.09(0.50)$ & $0.07(0.43)$ & $0.06(0.37)$ \\
\hline & {$[-0.18,0.95]$} & {$[-0.15,0.78]$} & {$[-0.17,0.81]$} \\
\hline \multirow[t]{2}{*}{ Industry 2} & $0.18(0.56)$ & 0.29 & $0.27(0.95)$ \\
\hline & {$[-0.26,0.91]$} & {$[0.23,0.98]$} & {$[0.11,0.97]$} \\
\hline \multirow{2}{*}{ Industry 3} & $0.08(0.21)$ & $0.24(0.76)$ & $0.22(0.67)$ \\
\hline & {$[-0.22,0.56]$} & {$[0.12,0.78]$} & {$[-0.01,0.81]$} \\
\hline \multirow[t]{2}{*}{ Industry 4} & $0.01(0.03)$ & $0.12(0.40)$ & $0.10(0.32)$ \\
\hline & {$[-0.36,0.56]$} & {$[-0.12,0.71]$} & {$[-0.20,0.85]$} \\
\hline \multirow[t]{2}{*}{ Industry 5} & $0.25(0.61)$ & 0.40 & 0.38 \\
\hline & {$[-0.03,0.76]$} & {$[0.28,1.02]$} & {$[0.16,1.01]$} \\
\hline \multirow[t]{2}{*}{ Industry 6} & $0.03(0.14)$ & $0.11(0.60)$ & $0.09(0.48)$ \\
\hline & {$[-0.49,0.63]$} & {$[0.03,0.85]$} & {$[-0.20,0.87]$} \\
\hline \multirow{2}{*}{ Industry 7} & $0.18(0.52)$ & $0.31(1.01)$ & $0.29(0.94)$ \\
\hline & {$[0.03,0.70]$} & {$[0.28,0.93]$} & {$[0.18,0.92]$} \\
\hline \multirow[t]{2}{*}{ Industry 8} & $0.10(0.49)$ & $0.09(0.49)$ & $0.07(0.38)$ \\
\hline & {$[-0.65,1.14]$} & {$[-0.26,0.96]$} & {$[-0.42,0.95]$} \\
\hline \multirow[t]{2}{*}{ Industry 9} & $-0.04(-0.26)$ & $-0.06(-0.48)$ & $-0.06(-0.53)$ \\
\hline & {$[-0.51,0.13]$} & {$[-0.68,-0.00]$} & {$[-0.77,0.01]$} \\
\hline \multirow[t]{2}{*}{ Industry 10} & $0.09(0.35)$ & $0.16(0.77)$ & $0.15(0.68)$ \\
\hline & {$[-0.48,1.12]$} & {$[-0.29,1.42]$} & {$[-0.33,1.41]$} \\
\hline \multirow[t]{2}{*}{ Industry 11} & 0.19 & $0.21(1.50)$ & 0.20 \\
\hline & {$[0.50,1.24]$} & {$[0.74,1.46]$} & {$[0.63,1.46]$} \\
\hline \multirow[t]{2}{*}{ Industry 12} & $-0.06(-0.44)$ & $0.06(0.49)$ & $0.05(0.46)$ \\
\hline & {$[-0.67,-0.16]$} & {$[-0.00,0.79]$} & {$[-0.07,0.80]$} \\
\hline \multirow[t]{2}{*}{ Industry 13} & $-0.03(-0.14)$ & $0.07(0.33)$ & $0.06(0.27)$ \\
\hline & {$[-0.64,0.72]$} & {$[-0.28,0.88]$} & {$[-0.38,0.83]$} \\
\hline Direct Effects & & & \\
\hline Entrepreneurial Orientation & $0.30(2.86)^{* *}$ & $0.21(2.29)^{*}$ & $0.22(2.30)^{*}$ \\
\hline & {$[0.05,0.28]$} & {$[0.02,0.23]$} & {$[0.01,0.23]$} \\
\hline Absorptive Capacity & & $0.27(2.75)^{* *}$ & $0.28(2.42)^{*}$ \\
\hline & & {$[0.08,0.57]$} & {$[0.04,0.66]$} \\
\hline Improvisation & & $0.36(3.88)^{* *}$ & $0.35(3.59)^{* *}$ \\
\hline & & {$[0.14,0.57]$} & {$[0.13,0.58]$} \\
\hline Interaction Effects & & & \\
\hline EO $\times$ Absorptive Capacity & & & $0.01(0.13)$ \\
\hline & & & {$[-0.17,0.33]$} \\
\hline EO $\times$ Improvisation & & & $-0.06(-0.64)$ \\
\hline & & & {$[-0.29,0.14]$} \\
\hline Reqression Model Statistics & & & \\
\hline & 0.21 & 0.43 & 0.43 \\
\hline F-Value & 1.41 & $3.54 * *$ & $3.17 * *$ \\
\hline
\end{tabular}

PROCESS MEDIATION ANALYSIS (X = EO; $Y$ = Performance; $M_{1}=$ Absorptive Capacity; $M_{2}=$ 


\section{Improvisation; 5000 bootstrap):}

Direct Effect of X on Y

Indirect Effect of $\mathrm{X}$ on $\mathrm{Y}$ by $\mathrm{M}_{1}$

Total Effect of X on Y

Direct Effect of X on $\mathrm{M}_{1}$

Standardized Indirect Effect $b$

Preacher and Kelley $\kappa^{2}$

Conclusion of PROCESS Test

Direct Effect of $\mathrm{X}$ on $\mathrm{Y}$

Indirect Effect of $\mathrm{X}$ on $\mathrm{Y}$ by $\mathrm{M}_{2}$

Total Effect of X on $\mathrm{Y}$

Direct Effect of $\mathrm{X}$ on $\mathrm{M}_{2}$

Standardized Indirect Effect $b$

Preacher and Kelley $\kappa^{2}$

Effect Coefficient

$0.11 *[0.01,0.22]$

$0.07 * *[0.03,0.13]$

$0.18 * *[0.08,0.29]$

$0.15 * *[0.06,0.24]$

0.12 [0.05, 0.22]

$0.13[0.05,0.22]$

Absorptive Capacity mediation effect: Confirmed

$0.17 * *[0.07,0.27]$

$0.01[-0.03,0.06]$

$0.18 * *[0.08,0.29]$

$0.04[-0.07,0.15]$

$0.03[-0.05,0.11]$

$0.03[0.00,0.09]$
Standard Error

0.05

0.03

0.05

0.04

0.04

0.04 t-value

2.19

2.68

3.49

3.44

Conclusion of PROCESS Test

Notes: We report standardized regression coefficients with $t$-values in parentheses for the moderation analysis.

Values in square brackets represent bootstrapped 95\% Confidence Interval values (unstandardized coefficients) [LL, UL].

Industries: (1) Automotive \& Component Parts; (2) Building Materials \& Related Products; (3) Chemicals, Chemical \& Plastic Products; (4) Electrical \& Electronics Products; (5) Food, Beverages and Tobacco; (6) Furniture \& Wood Related Products; (7) Industrial \& Engineering Products; (8) Iron \& Steel Products; (9) Laboratory Equipment; (10) Packaging, Labeling \& Printing; (11) Pharmaceutical, Medical Equipment, Cosmetics, Toiletries \& Household; (12) Rubber Products; (13) Textiles \& Wearing Apparel.

** Significant at 0.01 level

* Significant at 0.05 level. 
Table 4. Conditional Effect of EO and Performance at Values of the Moderators

\begin{tabular}{|c|c|c|c|}
\hline $\begin{array}{l}\text { Absorptive Capacity value(s) } \\
\text { defining Johnson-Neyman } \\
\text { significance region(s) }\end{array}$ & $\begin{array}{l}\text { Value } \\
-0.04\end{array}$ & $\begin{array}{l}\text { \% below } \\
46.85\end{array}$ & $\begin{array}{l}\text { \% above } \\
53.15\end{array}$ \\
\hline $\begin{array}{l}\text { Moderator: Absorptive Capacity } \\
-0.53 \\
0.00 \\
0.53\end{array}$ & $\begin{array}{c}\text { Effect Coefficient } \\
0.05 \\
0.11^{*} \\
0.16^{*}\end{array}$ & $\begin{array}{c}\text { t-value } \\
0.74 \\
2.08 \\
2.48\end{array}$ & $\begin{array}{c}95 \% \text { CI (LL, UL) } \\
-0.09,0.20 \\
0.01,0.21 \\
0.03,0.29\end{array}$ \\
\hline $\begin{array}{l}\text { Improvisation value(s) defining } \\
\text { Johnson-Neyman significance } \\
\text { region(s) }\end{array}$ & $\begin{array}{l}\text { Value } \\
0.97 \\
-0.86\end{array}$ & $\begin{array}{l}\text { \% below } \\
93.69 \\
13.51\end{array}$ & $\begin{array}{l}\text { \% above } \\
6.31 \\
86.49\end{array}$ \\
\hline $\begin{array}{l}\text { Moderator: Improvisation } \\
+ \\
-0.63 \\
0.00 \\
0.63\end{array}$ & $\begin{array}{c}\text { Effect Coefficient } \\
0.18^{*} \\
0.17^{* *} \\
0.17^{* *}\end{array}$ & $\begin{array}{c}\text { t-value } \\
2.33 \\
3.47 \\
2.63\end{array}$ & $\begin{array}{c}\text { 95\% CI (LL, UL) } \\
0.03,0.33 \\
0.07,0.27 \\
0.04,0.29\end{array}$ \\
\hline
\end{tabular}

Table 5. ANOVA Results

\begin{tabular}{lccc}
\hline & \multicolumn{2}{c}{ Performance Group (Mean [SD]) } & \multicolumn{1}{c}{ F-value } \\
& Low Performers & High Performers & Between Groups \\
\hline Absorptive Capacity & $3.82(0.54)$ & $4.26(0.42)$ & $23.16^{* *}$ \\
Improvisation & $3.65(0.60)$ & $4.17(0.56)$ & $22.83^{* *}$ \\
\hline Notes: ** Significant at 0.01 level & &
\end{tabular}


Appendix A. Testing for common method bias: Regression results after partialling out correlation with the marker variable

\begin{tabular}{|c|c|c|c|}
\hline \multicolumn{4}{|l|}{ MODERATION ANALYSIS } \\
\hline \multirow[b]{2}{*}{ Variables } & & Regression Models & \\
\hline & Model 1 & Model 2 & Model 3 \\
\hline \multicolumn{4}{|c|}{ Control and Industry Dummy Variables } \\
\hline \multirow[t]{2}{*}{ Tenure } & $-0.01(-0.01)$ & $0.02(0.21)$ & $0.03(0.29)$ \\
\hline & {$[-0.12,0.12]$} & {$[-0.10,0.13]$} & {$[-0.10,0.15]$} \\
\hline \multirow[t]{2}{*}{ Firm Age } & $0.12(1.04)$ & $0.11(1.10)$ & $0.11(1.01)$ \\
\hline & {$[-0.07,0.18]$} & {$[-0.04,0.19]$} & {$[-0.04,0.18]$} \\
\hline \multirow[t]{2}{*}{ Firm Size } & $0.07(0.58)$ & $-0.00(-0.04)$ & $-0.01(-0.08)$ \\
\hline & {$[-0.15,0.32]$} & {$[-0.27,0.23]$} & {$[-0.29,0.25]$} \\
\hline \multirow[t]{2}{*}{ Industry 1} & $0.10(0.53)$ & $0.07(0.45)$ & $0.06(0.39)$ \\
\hline & {$[-0.08,1.00]$} & {$[-0.12,0.75]$} & {$[-0.15,0.81]$} \\
\hline \multirow[t]{2}{*}{ Industry 2} & $0.22(0.67)$ & $0.31(1.09)$ & $0.28(0.98)$ \\
\hline & {$[0.06,0.98]$} & {$[0.31,0.95]$} & {$[0.20,0.97]$} \\
\hline \multirow{2}{*}{ Industry 3} & $0.12(0.33)$ & $0.26(0.80)$ & $0.23(0.71)$ \\
\hline & {$[-0.23,0.63]$} & {$[0.14,0.82]$} & {$[0.04,0.86]$} \\
\hline \multirow[t]{2}{*}{ Industry 4} & $0.04(0.12)$ & $0.13(0.43)$ & $0.11(0.36)$ \\
\hline & {$[-0.39,0.58]$} & {$[-0.14,0.63]$} & {$[-0.20,0.71]$} \\
\hline \multirow[t]{2}{*}{ Industry 5} & $0.30(0.72)$ & $0.42(1.15)$ & $0.39(1.06)$ \\
\hline & {$[-0.14,0.82]$} & {$[0.35,1.029]$} & {$[0.30,1.03]$} \\
\hline \multirow[t]{2}{*}{ Industry 6} & $0.06(0.27)$ & $0.12(0.64)$ & $0.10(0.51)$ \\
\hline & {$[-0.49,0.72]$} & {$[0.11,0.92]$} & {$[-0.15,0.90]$} \\
\hline \multirow{2}{*}{ Industry 7} & $0.22(0.61)$ & $0.32(1.04)$ & $0.30(0.97)$ \\
\hline & {$[0.04,0.73]$} & {$[0.29,0.89]$} & {$[0.25,0.90]$} \\
\hline \multirow[t]{2}{*}{ Industry 8} & $0.14(0.65)$ & $0.10(0.55)$ & $0.08(0.43)$ \\
\hline & {$[-0.32,1.39]$} & {$[-0.19,1.03]$} & {$[-0.45,1.05]$} \\
\hline \multirow[t]{2}{*}{ Industry 9} & $-0.02(-0.11)$ & $-0.05(-0.43)$ & $-0.06(-0.49)$ \\
\hline & {$[-0.39,0.32]$} & {$[-0.67,0.12]$} & {$[-0.79,0.11]$} \\
\hline \multirow[t]{2}{*}{ Industry 10} & $0.12(0.49)$ & $0.17(0.82)$ & $0.16(0.73)$ \\
\hline & {$[-0.41,1.26]$} & {$[-0.36,1.45]$} & {$[-0.35,1.31]$} \\
\hline \multirow[t]{2}{*}{ Industry 11} & 0.19 & 0.21 & 0.21 \\
\hline & {$[0.34,1.26]$} & {$[0.71,1.46]$} & {$[0.65,1.46]$} \\
\hline \multirow[t]{2}{*}{ Industry 12} & $-0.06(-0.45)$ & $0.06(0.49)$ & $0.05(0.46)$ \\
\hline & {$[-0.66,-0.14]$} & {$[0.05,0.71]$} & {$[0.02,0.75]$} \\
\hline \multirow{2}{*}{ Industry 13} & $-0.01(-0.04)$ & $0.08(0.36)$ & $0.06(0.30)$ \\
\hline & {$[-0.51,0.83]$} & {$[-0.20,0.83]$} & {$[-0.25,0.85]$} \\
\hline \multicolumn{4}{|l|}{ Direct Effects } \\
\hline \multirow[t]{2}{*}{ Entrepreneurial Orientation } & $0.30(2.83)^{* *}$ & $0.22(2.32)^{*}$ & $0.22(2.33)^{*}$ \\
\hline & {$[0.05,0.30]$} & {$[0.02,0.24]$} & {$[0.02,0.26]$} \\
\hline \multirow[t]{2}{*}{ Absorptive Capacity } & & $0.27(2.71)^{* *}$ & $0.29(2.55)^{* *}$ \\
\hline & & {$[0.05 .0 .55]$} & {$[0.05,0.62]$} \\
\hline Improvisation & & $0.36(3.86)^{* *}$ & $0.35(3.53)^{* *}$ \\
\hline & & {$[0.19,0.55]$} & {$[0.11,0.60]$} \\
\hline Interaction Effects & & & \\
\hline EO $\times$ Absorptive Capacity & & & $0.03(0.27)$ \\
\hline & & & {$[-0.15,0.35]$} \\
\hline EO $\times$ Improvisation & & & $-0.06(-0.68)$ \\
\hline & & & {$[-0.26,0.10]$} \\
\hline Regression Model Statistics & & & \\
\hline$R^{2}$ & 0.19 & 0.41 & 0.41 \\
\hline F-Value & 1.29 & $3.31 * *$ & $2.97 * *$ \\
\hline
\end{tabular}


PROCESS MEDIATION ANALYSIS (X = EO; $Y$ = Performance; $M_{1}=$ Absorptive Capacity; $\mathbf{M}_{2}=$ Improvisation; 5000 bootstrap):

Direct Effect of $\mathrm{X}$ on $\mathrm{Y}$

Indirect Effect of $\mathrm{X}$ on $\mathrm{Y}$ by $\mathrm{M}_{1}$ Total Effect of $\mathrm{X}$ on $\mathrm{Y}$

Direct Effect of $\mathrm{X}$ on $\mathrm{M}_{1}$ Standardized Indirect Effect $b$ Preacher and Kelley $\kappa^{2}$ Conclusion of PROCESS Test

\section{Direct Effect of $\mathrm{X}$ on $\mathrm{Y}$}

Indirect Effect of $\mathrm{X}$ on $\mathrm{Y}$ by $\mathrm{M}_{2}$

Total Effect of $\mathrm{X}$ on $\mathrm{Y}$

Direct Effect of X on $\mathrm{M}_{2}$ Standardized Indirect Effect $b$ Preacher and Kelley $\kappa^{2}$ Conclusion of PROCESS Test Effect Coefficient $0.11 *[0.01,0.21]$ $0.07 * *[0.03,0.12]$

Standard Error 0.05

0.02

0.05

$0.18 * *[0.07,0.28]$

$0.14 * *[0.05,0.22]$

$0.11[0.04,0.20]$

$0.11[0.04,0.20]$

Absorptive Capacity mediation effect: Confirmed

$t$-value

2.13

2.50

3.27

3.15

0.04

0.04

0.05

3.37

$0.16 * *[0.07,0.26]$

$0.01[-0.03,0.06]$

$0.18^{* *}[0.07,0.28]$

0.02

0.05

0.47

$0.03[-0.08,0.14]$

0.06

$0.02[-0.06,0.10]$

0.04

$0.02[0.00,0.07]$

0.03

Improvisation mediation effect: None

\footnotetext{
Notes: We report standardized regression coefficients with $t$-values in parentheses. Values in square brackets represent bootstrapped 95\% Confidence Interval values (unstandardized coefficients) [LL, UL]. Industries: (1) Automotive \& Component Parts; (2) Building Materials \& Related Products; (3) Chemicals, Chemical \& Plastic Products; (4) Electrical \& Electronics Products; (5) Food, Beverages and Tobacco; (6) Furniture \& Wood Related Products; (7) Industrial \& Engineering Products; (8) Iron \& Steel Products; (9) Laboratory Equipment; (10) Packaging, Labeling \& Printing; (11) Pharmaceutical, Medical Equipment, Cosmetics, Toiletries \& Household; (12) Rubber Products; (13) Textiles \& Wearing Apparel.

** Significant at 0.01 level

* Significant at 0.05 level.
} 